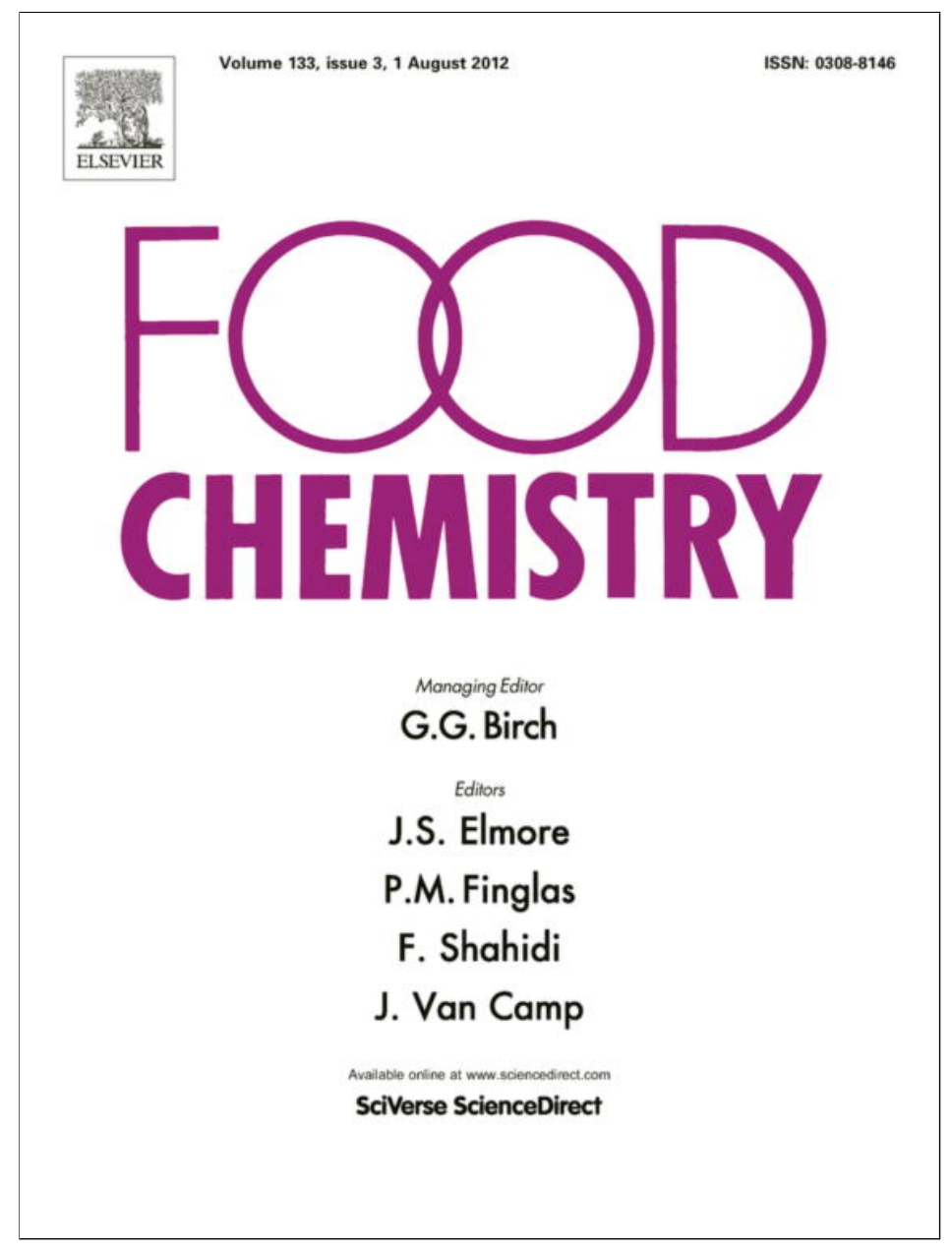

This article appeared in a journal published by Elsevier. The attached copy is furnished to the author for internal non-commercial research and education use, including for instruction at the authors institution and sharing with colleagues.

Other uses, including reproduction and distribution, or selling or licensing copies, or posting to personal, institutional or third party websites are prohibited.

In most cases authors are permitted to post their version of the article (e.g. in Word or Tex form) to their personal website or institutional repository. Authors requiring further information regarding Elsevier's archiving and manuscript policies are encouraged to visit:

http://www.elsevier.com/copyright 
Analytical Methods

\title{
Identification of tuna species by a real-time polymerase chain reaction technique
}

\author{
Po-Shun Chuang, Meng-I Chen, Jen-Chieh Shiao* \\ Institute of Oceanography, College of Science, National Taiwan University, No. 1, Section 4, Roosevelt Road, Taipei, Taiwan 106, ROC
}

\section{A R T I C L E I N F O}

\section{Article history:}

Received 18 October 2011

Received in revised form 9 January 2012

Accepted 24 January 2012

Available online 1 February 2012

\section{Keywords:}

Tuna

Species identification

Real-time PCR

\begin{abstract}
A B S T R A C T
Tuna are highly priced fishes that are often used in processed products. For effective fishery management and protection of consumers' rights, it is important to develop a molecular method to identify the species of the tuna products. In this study we have developed a molecular method based on real-time polymerase chain reaction (real-time PCR) technology for the rapid identification of four tuna species. Four speciesspecific TaqMan probes were designed to identify bigeye tuna (Thunnus obesus), Pacific bluefin tuna (Thunnus orientalis), southern bluefin tuna (Thunnus maccoyii), and yellowfin tuna (Thunnus albacares). A SYBR green system was also designed to enhance the authentication of $T$. obesus. Both systems can distinguish target species from others in an efficient and high-throughput manner and can be applied to species identification of tuna products.
\end{abstract}

(c) 2012 Elsevier Ltd. All rights reserved.

\section{Introduction}

There are eight species in the genus Thunnus (Chow \& Kishino 1995; Takeyama, Chow, Tsuzuki, \& Matunaga, 2001), which are highly prized. As most tuna manufactured products are traded in vacuum-packed slices, loins, or canned products (Dalmasso et al., 2007), identification of these fish products from morphological characteristics is not possible. Since each tuna species has a different quality and price, a fraudulent replacement of valuable species by less valuable ones may at times occur (Pardo \& Pérez-Villareal 2004). Therefore, for effective management and the protection of consumer rights, a molecular method is needed for the species identification of tuna products when the external features are not available.

Several molecular methodologies are presently available for content identification in seafood products (Rasmussen \& Morrissey 2008; Teletchea 2009). Among them, polymerase chain reactionrestriction fragment length polymorphism (PCR-RFLP) is the most common methodology used for fish species identification. Takeyama et al. (2001) modified the method from Chow and Inoue (1993), and showed that all tuna species can be distinguished by the RFLP method. However, due to the high degree of homology of the DNA sequences among Thunnus species (Bottero, Dalmasso, Cappelletti, Secchi, \& Civera, 2007), the complete discrimination of Thunnus species required five different restriction enzymes and the whole procedure was complicated.

FINS (forensically informative nucleotide sequencing) is the most accurate technology for species authentication (Bartlett \&

\footnotetext{
* Corresponding author. Tel.: +886 2 33663227; fax: +886233663744.

E-mail address: jcshiao@ntu.edu.tw (J.-C. Shiao).
}

Davidson, 1992). This PCR and DNA-sequencing method has been used in many studies of species identification or phylogenetic relationship rebuilding (Chow \& Kishino, 1995; Tseng, Shiao, \& Hung, 2011; Viñas \& Tudela, 2009). Botti and Giuffra (2010) described a primer cocktail to amplify and sequence a 226-bp fragment of Cytb gene, which was able to identify 17 species of the Scombridae. However, the cost and longer time required for the DNA-sequencing method hampered its large-scale applicability. These disadvantages make both of these techniques unsuitable for high-throughput examination.

Real-time PCR techniques have been widely used for species identification or GMOs examination in recent years (Alary et al., 2002; Bertoja, Giaccone, Carraro, Mininni, \& Cardazzo, 2009; Rodriguez-Lazaro, Hernandez, Esteve, Hoorfar, \& Pla, 2003). The main advantages of real-time PCR are high sensitivity, high specificity, excellent efficiency, reduced amplicon size, and no post-PCR steps that increase the risks of cross-contamination (RodriguezLazaro et al., 2003). Lopez and Pardo (2005) have developed two TaqMan systems to identify two tuna species, $T$. alalunga and $T$. albacares. Dalmasso et al. (2007) developed a system that combined the FRET (fluorescence resonance energy transfer) probe and melting curve analysis to identify four tuna species, including T. thynnus, T. albacares, T. alalunga and T. obesus. Terio et al. (2010) also developed three MGB (minor groove binder) probe assays that can identify $T$. albacares, $T$. thynnus, and $T$. alalunga from each other in both fresh and canned tuna.

Another methodology based on real-time PCR technology is the SYBR green system (Wittwer, Herrmann, Moss, \& Rasmussen, 1997), which is a fluorescent molecule that can bind to the minor groove of DNA double strands and emit fluorescence after being excited by certain wavelengths $(\lambda=488 \mathrm{~nm})$. It can be applied 
quantitatively by counting the differences in the threshold cycle between the detection system and internal control $(\Delta C t)$ (Ponchel et al., 2003), or analysed qualitatively via the melting temperature of the PCR products (melting curve analysis) (Ririe, Rasmussen, \& Wittwer, 1997).

In this study, we developed three TaqMan probes and a modified probe from Lopez and Pardo (2005), as well as an SYBR system, that were capable of rapid and high-throughput identification of bigeye tuna (BET) Thunnus obesus (Lowe, 1839), Pacific bluefin tuna (PBT) T. orientalis (Temminck \& Schlegel, 1844), southern bluefin tuna (SBT) T. maccoyii (Castelnau, 1872), and yellowfin tuna (YFT) T. albacares (Bonnaterre, 1788). The whole procedure, including DNA extraction, significantly reduces the experimental time to within half a working day and makes large-scale examination more applicable.

\section{Materials and methods}

\subsection{Sample collection}

\subsubsection{Raw materials}

Five tuna species were collected for this study. Muscle tissues from T. obesus $(n=17), T$. orientals $(n=26), T$. albacares $(n=52)$, and T. alalunga $(n=24)$ were collected from Tong Gang, southern Taiwan from 2008 through 2009. Specimens of T. maccoyii $(n=33)$ were collected by scientific observers from the Indian Ocean in 2008. These samples were used for the preliminary DNA sequencing work and to search for a suitable genetic marker for the primers and probes designation.

Each of the five tuna species described above were also collected for muscle tissues by scientific observers in the three major ocean basins (the Atlantic, Indian, and Pacific Oceans) in 2009 from spring to summer $(n=225)$. Species were identified and labelled according to their morphological traits during the sampling. These muscle tissues were frozen and transported to the laboratory where the tissues were transferred to $95 \%$ ethanol at room temperature. Then, the species of all samples were identified with the designed probes and primers by real-time PCR.

\subsubsection{Canned tuna}

Six cans made by 2 companies (company AGV and SH) labelled with tuna meat were purchased from local markets. The DNA was extracted for species identification by real-time PCR using the probes and primers described below.

\subsection{DNA extraction}

DNA was extracted from all of the specimens following the protocol of DNeasy Blood \& Tissue Kit (QIAGEN, Düsseldorf, Germany) and the extracted DNA samples were preserved at $-20^{\circ} \mathrm{C}$.

\subsection{Markers selection and detection systems design}

For the design of the probe systems, sequences of the mitochondrial genes Cytochrome b (1257 bp; F: 5'-ACCAGGACTAATGGCTTG3'; R: 5'-AGGATTTTAACCTCCGACGTC-3'), and D-loop region (971 bp; F: 5'-GGGCCCATCTTAACATCTTC-3'; R: 5'-GGGCCCATCTTA ACATCTTC- $3^{\prime}$ ) were obtained from the test samples in a preliminary study. These sequences were then aligned with the published sequences from GenBank (Cytb: AB185022, DQ198013, EF141183, GU256526 and GU256528; D-loop region: HQ630704-HQ630705 and HQ630707-HQ630709) using MEGA 5 to find suitable diagnostic sites for species identification. For the internal control of the TaqMan probe systems, sequences of mitochondrial $16 \mathrm{~S}$ gene from GenBank (GU256522-GU256526, GU256528, GU325784, JN0861149-JN086150 and JN086152-JN086154) were downloaded and searched for conservative regions for the design of primers and probe.

In the SYBR green system, ATPase6 was chosen as the marker for BET identification. Nine DNA sequences of the mitochondrial gene ATPase6 were downloaded from GenBank (AF115273AF115278, AF260430, AB185022 and GU256526) and aligned by MEGA 5 to design species-specific primers. The internal control for the SYBR green system was designed in the mitochondrial $16 S$ gene using the same reference sequences of the probe internal control system.

The primer pairs described above were synthesised by MISSION BIOTECH (Taipei, Taiwan) and the probes used in real-time PCR were designed by Primer Premier 5 (PremierBiosoft International, Palo Alto, CA) and synthesised by Applied Biosystems (Foster City, CA). DNA sequences of TaqMan and SYBR green system are shown in Table 1.

\subsection{Real-time PCR procedure (TaqMan systems)}

Each TaqMan system was used in simplex real-time PCR reaction, with the internal control conducted in the separate wells. Total volume of each reaction was adjusted to $25 \mu \mathrm{L}$, containing $12.5 \mu \mathrm{L}$ SuperMix (BioRad Laboratories, Hercules, CA), $0.5 \mu \mathrm{M}$ of

Table 1

DNA sequence of the probes and primers for the TaqMan and SYBR green systems. The TaqMan systems were named according to the target species and the position of the diagnostic site, the parentheses under the probe's name indicated the mitochondrial genes. The SYBR green system was named according to the marker gene ATPase6 and the target species, the BigEyeTuna. The parentheses before the primers indicated their directions: forward (F) or reverse (R). BET: T. obesus. PBT: T. orientalis. SBT: T. maccoyii. YFT: T. albacares. The asterisk indicated the probe system modified from Lopez and Pardo (2005).

\begin{tabular}{|c|c|c|c|c|c|}
\hline Probe & Target species & $\mathrm{P}$ & Primers $\left(5^{\prime} \rightarrow 3^{\prime}\right)$ & Probe $\left(5^{\prime} \rightarrow 3^{\prime}\right)$ & Amplicon \\
\hline BET588 (Cytb) & T. obesus & & $\begin{array}{l}\text { (F) AGGCTTTTCAGTAGACAATGC } \\
\text { (R) TGGATTATTTGAACCTGTTTCG }\end{array}$ & 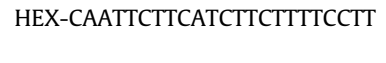 & 127 (bp) \\
\hline PBT281 (D-loop) & T. orientalis & $(1$ & $\begin{array}{l}\text { (F) CCCTCATCTCTGAAATCTAGTAAAC } \\
\text { (R) ACCTTCAATAACCGTATGCAT }\end{array}$ & FAM-CATCCAGCTCATTTCTTA & 82 (bp) \\
\hline SBT375 (Cytb) & T. maccoyii & (1) & $\begin{array}{l}\text { (F) AAACATGAAACATCGGAGTAGTACTC } \\
\text { (R) CATATGGGACTGCGGATA }\end{array}$ & HEX-AGTTATGATAACCGCCTTC & 135 (bp) \\
\hline *YFT330 (Cytb) & T. albacares & $\begin{array}{ll}(\mathrm{H} \\
(\mathrm{H}\end{array}$ & $\begin{array}{l}\text { (F) CGAGGACTTTACTACGGCTCTT } \\
\text { (R) CGGTCATCATAACTAGGAGTAGGAGTAC }\end{array}$ & FAM-CCTATACAAGGAAACATGAAA & $82(\mathrm{bp})$ \\
\hline $16 S(16 S)$ & Thunnus spp. & $\begin{array}{ll}(\mathrm{H} \\
(\mathrm{H}\end{array}$ & $\begin{array}{l}\text { (F) CCCCTAGTATGGGCGACAGA } \\
\text { (R) CGTTCCCTTGCGGTACTTTC }\end{array}$ & FAM-AAGGAACTATTGGAGCGATA & $63(\mathrm{bp})$ \\
\hline SYBR & & Species & Primers $\left(5^{\prime} \rightarrow 3^{\prime}\right)$ & & Amplicon \\
\hline ATP_BET (ATPase6) & & T. obesus & $\begin{array}{l}\text { (F) GGCCACAAAT } \\
\text { (R) ACCTTCTCGG }\end{array}$ & $\begin{array}{l}\text { ГCCT } \\
\text { CCCGTCA }\end{array}$ & 683 (bp) \\
\hline $16 S(16 S)$ & & Thunnus spp. & $\begin{array}{l}\text { (F) AACAAGAGAC } \\
\text { (R) AGGGTAACTC }\end{array}$ & $\begin{array}{l}\text { ECTCTCTCCTTGCACACG } \\
\text { ГTGATCGGCGTTGC }\end{array}$ & 643 (bp) \\
\hline
\end{tabular}


each primer, $0.2 \mu \mathrm{M}$ of probe, and $50 \mathrm{ng}$ of DNA template. The reaction was initiated at a stabilising phase of $50^{\circ} \mathrm{C}$ for $2 \mathrm{~min}$, then a denaturing phase at $95^{\circ} \mathrm{C}$ for $10 \mathrm{~min}$, followed by 40 cycles of $95^{\circ} \mathrm{C}$ for $15 \mathrm{~s}$ and $60^{\circ} \mathrm{C}\left(65^{\circ} \mathrm{C}\right.$ for probe_BET588) for $1 \mathrm{~min}$.

\subsection{Real-time PCR procedure (SYBR green system)}

The SYBR green system was carried out in a total volume of $20 \mu \mathrm{L}$ containing $10 \mu \mathrm{L}$ SsoFast ${ }^{\mathrm{TM}}$ EvaGreenSuperMix (BioRad), $0.5 \mu \mathrm{M}$ of each primer, and $50 \mathrm{ng}$ of extracted DNA. The reaction was initiated at a denaturation phase at $95^{\circ} \mathrm{C}$ for $3 \mathrm{~min}$, followed by 40 cycles of $95^{\circ} \mathrm{C}$ for $11 \mathrm{~s}, 69^{\circ} \mathrm{C}$ for $20 \mathrm{~s}$, and finished with a denaturation step at $95^{\circ} \mathrm{C}$ for $1 \mathrm{~min}$.

Both the TaqMan systems and SYBR green system were used with a Bio-Rad $\mathrm{iQ}^{\mathrm{TM}} 5$ real time PCR detection system.

\subsection{Real-time PCR efficiency test}

Three individuals of each tuna species were used to evaluate the efficiencies and sensitivities of the TaqMan and SYBR green systems. For each individual, DNA concentrations were adjusted by fivefold serial dilution to the final DNA concentrations of 50 , $10,2,0.4$, and $0.08 \mathrm{ng}$ per reaction. The efficiency was estimated by plotting $C t$ values against the logarithm of the DNA concentration $(\mathrm{ng} / \mathrm{rxn})$, with the efficiency $=\left[10^{(-1 / \text { slope })}-1\right] \times 100 \%$.

\subsection{Sequencing for species confirmation}

To confirm the results of real-time PCR identification, two samples for each species were randomly chosen and sequenced at the fragment of the genes containing the annealing region of each system. The primers used in sequencing were the same as those described in markers selection and primers design. For the SYBR green system, another primer pair was used to sequence the fragment of the ATPase 6 gene (1027 bp; F: 5'-ATTCCCAACACCAAC ATCC-3'; R: 5'-GAACGGAGACCTCAATGTCAAT-3'). DNA sequencing was also conducted for the samples with morphological identifications conflicting with the identification result by real-time PCR. The sequenced data were then compared with the sequences downloaded from GenBank to confirm the species of the sample.

The PCR procedure was carried out in a total volume of $25 \mu \mathrm{L}$ containing $0.5 \mu \mathrm{L}$ Taq DNA polymerase ( $5 \mathrm{U} / \mu \mathrm{L}$, Protech), $250 \mathrm{nM}$ dNTPs (TaKaRa), $2.5 \mu \mathrm{L} 10 \times$ reaction buffer $(100 \mathrm{mM}$ Tris- $\mathrm{HCl}$, $\mathrm{pH}$ 9.0, $50 \mathrm{mM} \mathrm{KCl}, 0.1 \%\left(\mathrm{w} / \mathrm{v}\right.$ ) gelatin, $1.5 \mathrm{mM} \mathrm{MgCl}_{2}, 1 \%$ Triton $\mathrm{X}-100$, Protech), $10 \mu \mathrm{M}$ of each primer, and $50 \mathrm{ng}$ of DNA extracted previously. The reaction was initiated at $95^{\circ} \mathrm{C}$ for $3 \mathrm{~min}$, followed by 35 cycles of $95^{\circ} \mathrm{C}$ for $30 \mathrm{~s}, 55^{\circ} \mathrm{C}$ for $30 \mathrm{~s}, 72^{\circ} \mathrm{C}$ for $60 \mathrm{~s}$, and finished with a final extension step at $72{ }^{\circ} \mathrm{C}$ for $5 \mathrm{~min}$. The PCR procedure was conducted in a TaKaRa PCR Thermal Cycler Dice ${ }^{\mathrm{TM}}$ (TaKaRa Bio Inc., Shiga, Japan).

The confirmatory test of DNA sequence was done by conducting phylogenetic analysis in the MEGA 5 program with sequences downloaded from GenBank using the maximal likelihood (ML) method and neighbour-joining (NJ) methods. The evolutional model applied in each tree-building process was chosen by the software JmodelTest 0.1.1 (Posada 2008).

\subsection{Data analysis}

For both the TaqMan and SYBR green systems, the internal control was used as the checkpoint for the quality of DNA samples. If the sample could not be effectively amplified and detected by the internal control primers and probe, the data were not included for further analysis. The success of identification was determined according to the $\Delta C t$ and fluorescent endpoint value. All the realtime PCR data was exported and re-plotted using Matlab 7.10.0.
$\Delta C t$ and fluorescent endpoint value between target species and non-target species were compared using Student's test and significance level $\alpha$ was set at 0.05 .

\section{Results and discussions}

\subsection{Marker selection and diagnostic site searching}

A total of 129 individuals were successfully sequenced for the $C y t b$ gene and 42 samples for the D-loop region. From the Cytb gene sequences obtained, 6 variation sites were found specific to BET, 2 to PBT, 6 to SBT, and 2 to YFT. In the sequences of the D-loop region, 1, 4, 5 and 1 species-specific variations were found for BET, PBT, SBT, and YFT, respectively. In the Cytb gene, probe_BET588 was designed at the region covering site 588 (reference sequence: DQ198013), where BET individuals possessed $T$ in contrast to $C$ in other species. Probe_SBT375 was designed to detect the A in SBT at site 375 (reference sequence: EF141183), while other species possessed G in this variation site. The 330th site of the Cytb sequence (reference sequence: DQ080281) of YFT showed a G in contrast to A in other species. This diagnostic site (named as Probe_YFT330 in this study) was identical to the one found by Lopez and Pardo (2005). However, the forward primer (CGAGGCCTTTACTACGGCTCTT) in Lopez and Pardo (2005) was modified to CGAGGACTTTACTACGGCTCTT to fit our sequencing results. In the D-loop region, probe_PBT281 was designed to detect a small reversion in which PBT demonstrated CT, while other species were TC at sites 281-282 (reference sequence: HQ630709). Multiple alignments of the DNA sequence for each probe system are provided in Supplementary data (Fig. S1).

No diagnostic site was found specific to T. alalunga (ALB) in the present study, thus the probe and primers specific to ALB identification cannot be designed. Although the ALB probe published by Lopez and Pardo (2005) could successfully distinguish ALB from YFT, BET, and BFT (T. thynnus), the sequence of the ALB probe (TCCA CATCGCCGAGGCCTTTACTA) was inconsistent to our sequencing result of ALB with an insertion of a $G$ in the middle of the probebinding region in all of our ALB samples (TCCACATCGGCCGAGG CCTTTACTA). Our sequencing result also revealed that the ALB probes used by Lopez and Pardo (2005), and Terio et al. (2010) could not distinguish ALB from PBT because they share the same sequence in both the primers- and probe-binding regions.

In total, 45 diagnostic sites were found in the ATPase 6 gene. Among them, the 190th, the 831th and the 843th variation sites (reference sequence: AF115273) were chosen to design the species-specific primer pairs for BET identification by the SYBR green method. The multiple alignments of the primer-binding regions of the reference sequences are shown in Supplementary data of Table S1.

\subsection{Real-time PCR efficiency}

The linearity of the probe and SYBR green systems were consistent in detection and internal control systems, indicating the robustness of $\Delta \mathrm{Ct}$ as a criterion in different DNA concentrations from $0.08 \mathrm{ng}$ to $50 \mathrm{ng}$ (Fig. S2). The efficiencies for all the systems ranged from $102.84 \%$ to $120.59 \%$, except for the probe_BET588 system, which were $86.18 \%$ and $83.11 \%$ for the detection and internal control, respectively. The reduced efficiencies of probe_BET588 system could be due to the higher annealing temperature $\left(65^{\circ} \mathrm{C}\right)$, but the lower efficiency did not hamper the discriminating results.

\subsection{Identification of four Thunnus species by TaqMan systems}

The major goal of the present research was to identify BET, PBT, SBT, and YFT from five Thunnus species (including ALB) by 
real-time PCR. Due to the deviations arising from different mitochondria copy numbers among species, individuals and the tissues extracted (Ballin, Vogensen, \& Karlsson, 2009; Lopez \& Pardo 2005), the $\Delta$ Cts rather than Cts of the experimental system were used as the identification criteria (Table 2).

For the samples successfully detected, the mean $C t( \pm \mathrm{SD})$ of the 16S TaqMan system was $23.56 \pm 2.57$ ( $n=157$, Fig. $1 \mathrm{a}$ and b). For the four species-specific TaqMan probe systems, the $\Delta C t$ ts and RFUs showed great discrimination between the target and non-target species (Student's $t$-test, $p<0.001$ for all four systems, Table 2).

Among the four TaqMan systems, probe_SBT375 and probe_YFT330 demonstrated the greatest discrimination in the real-time PCR profile (Fig. 1c and d), with $\Delta C$ ts close to 0 and fluorescence endpoint values greater than $1000 \mathrm{RFUs}$ for the target species (>2000 RFUs in probe_SBT375). The signals of non-target species for these two systems only expressed fluorescence less than 500 RFUs and $\Delta$ Cts greater than 15 . The large differences in $\Delta C t s$

Table 2

Mean ( \pm SD) $\Delta$ Cts and fluorescence endpoint values (RFUs) for each system. Samples were divided into 2 groups according to the identification target of each system respectively. The sample number was presented as N = YFT + PBT + ALB + SBT + BET. YFT: T. albacares. PBT: T. orientalis. ALB: T. alalunga. SBT: T. maccoyii. BET: T. obesus.

\begin{tabular}{|c|c|c|c|c|}
\hline & Signals & Non-target species & Target species & $p$-Value \\
\hline \multicolumn{5}{|l|}{ Probe system } \\
\hline \multirow[t]{3}{*}{ Probe_BET588 } & RFUs & $160.8 \pm 182.8$ & $1076.6 \pm 451.9$ & $<0.001$ \\
\hline & $\Delta C t$ & $14.47 \pm 2.52$ & $5.76 \pm 5.85$ & $<0.001$ \\
\hline & $N$ & $25+13+19+18+0=75$ & 51 & \\
\hline \multirow[t]{3}{*}{ Probe_PBT281 } & RFUs & $555.9 \pm 498.7$ & $2804.3 \pm 515.4$ & $<0.001$ \\
\hline & $\Delta C t$ & $14.51 \pm 4.25$ & $-4.06 \pm 3.63$ & $<0.001$ \\
\hline & $N$ & $28+0+19+18+72=137$ & 14 & \\
\hline \multirow[t]{3}{*}{ Probe_SBT375 } & RFUs & $293.6 \pm 331.5$ & $2561.7 \pm 480.3$ & $<0.001$ \\
\hline & $\Delta C t$ & $15.59 \pm 3.48$ & $-0.24 \pm 3.09$ & $<0.001$ \\
\hline & $N$ & $26+13+19+0+52=110$ & 16 & \\
\hline \multirow[t]{3}{*}{ Probe_YFT330 } & RFUs & $99.3 \pm 110.4$ & $1538.3 \pm 420.1$ & $<0.001$ \\
\hline & $\Delta C t$ & $16.25 \pm 2.62$ & $0.56 \pm 3.85$ & $<0.001$ \\
\hline & $N$ & $0+13+19+17+51=100$ & 26 & \\
\hline \multicolumn{5}{|c|}{ SYBR green system } \\
\hline \multirow[t]{3}{*}{ ATP_BET } & Cts & $30.52 \pm 4.00$ & $22.37 \pm 2.68$ & $<0.001$ \\
\hline & $\Delta C t$ & $8.64 \pm 3.89$ & $0.25 \pm 1.25$ & $<0.001$ \\
\hline & $N$ & $48+17+23+16+0=104$ & 110 & \\
\hline
\end{tabular}


Fig. 1. Real-Time PCR profile of TaqMan systems. (a and b) The internal control by probe_16S, (c) probe_SBT375, (d) probe_YFT330, (e) probe_PBT281 and (f) probe_BET588. 
and fluorescence endpoint values made it easy to discriminate the target species from others without ambiguity. In probe_PBT281, the fluorescence of the non-target species reached more than 1000 RFUs in some individuals (Fig. 1e). However, this did not hamper the identification procedure since the target species (PBT) demonstrated the highest signal range from 2000 to 3500 RFUs. In contrast to the other three TaqMan systems, probe_BET588 expressed less discrimination among species (Fig. 1f). The larger $\Delta$ Cts and lower fluorescence endpoint values of the BET might be due to the higher annealing temperature $\left(65^{\circ} \mathrm{C}\right)$, which reduced the binding affinity of primers and probe. In the probe_BET588 system, 6 out of 12 BET individuals collected from the Atlantic Ocean (BET_A) were misidentified as non-BET species, while no misidentification was detected from the samples collected from other ocean basins. The sequence information of the 6 misidentified BET_A individuals demonstrated that intraspecies variation existed in the primer- and probe-binding region, where the 6 BET_A individuals possessed a $G$ in the $5^{\prime}$-end of the forward primer instead of an A in other BET individuals, and a $C$ in the centre of the probe instead of a $T$ in the reference sequence (DQ198013) of BET (Fig. S3). This phenomenon can be explained by the existence of two clades of mitochondrial genome in the Atlantic BET population that differentiates from IndoPacific stock (Alvarado-Bremer, Stequert, Robertson, \& Ely, 1998; Chow, Okamoto, Miyabe, Hiramatsu, \& Barut, 2000; Gonzalez, Beerli, \& Zardoya, 2008). However, this intraspecies variation was studied mostly in the ATCO and D-loop control region as well as the nuclear microsatellites of BET (Durand, Collet, Chow, Guinand, \&
Borsa, 2005) and no evidence from the Cytb gene has been previously published. The phylogenetic analysis of the BET samples indicated that these six individuals collected from the Atlantic Ocean self-aggregated into a group that distinguished them from other BET individuals that were successfully identified by real-time PCR (Fig. 2). This evidence supports the existence of clade differentiation in the Cytb gene of $T$. obesus. The identification and sequencing results of the other three Thunnus species showed no variation between ocean basins, consistent with the results of Takeyama et al. (2001).

\subsection{Identification of T. obesus by the SYBR green system}

In the SYBR green system, the mean $\Delta C t( \pm$ SD) was $0.25 \pm 1.25$ $(n=110)$ for BET samples and $9.01 \pm 3.49$ for non-target species ( $n=100$, Table 2 ). The real-time PCR profile of this system showed a larger range of $C t s$ distribution and fluorescence saturation in BET individuals. Non-target species also demonstrated high fluorescent signals at the end of the real-time PCR procedure (Fig. 3). Due to these phenomena, the fluorescence endpoint values were not used as criteria for species discrimination.

Although the SYBR green system was designed in the fragment of ATPase6 gene, where mitochondrial clade differentiation of BET was discovered, there is no intraspecies variation detected in this system. Therefore, this system can be applied as a supplementary test with probe_BET588 to identify BET species. For other species used in this study, there is no need to develop an additional SYBR

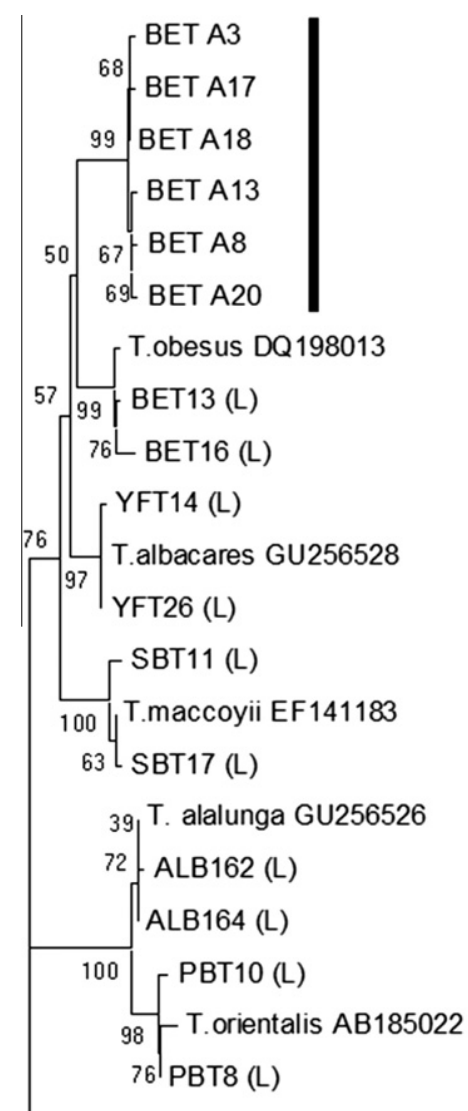

Auxis rochei EF439498

$$
\longmapsto_{0.02} \text { substitutions/site }
$$

Fig. 2. Neighbour-Joining (NJ) tree based on TN93 + G model. Cytb gene fragment of 911 bp was analysed and Auxis thazard (EF439498) was selected as the outgroup. The samples labelled with (L) represent no ambiguity in identification. The black vertical line highlights the 6 BET individuals collected from the Atlantic Ocean (labelled with A), which showed inconsistency between probe_BET588 and morphological identification. Bootstrap replications $=1000$. 


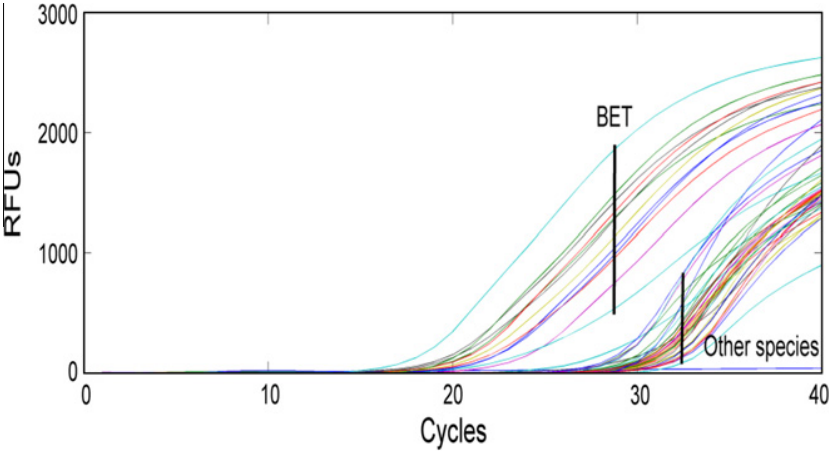

Fig. 3. Real-time $P C R$ profiles of the SYBR green system. The $C t$ values of BET samples ranged from 20 to 25, while other species showed $C t$ values larger than 30
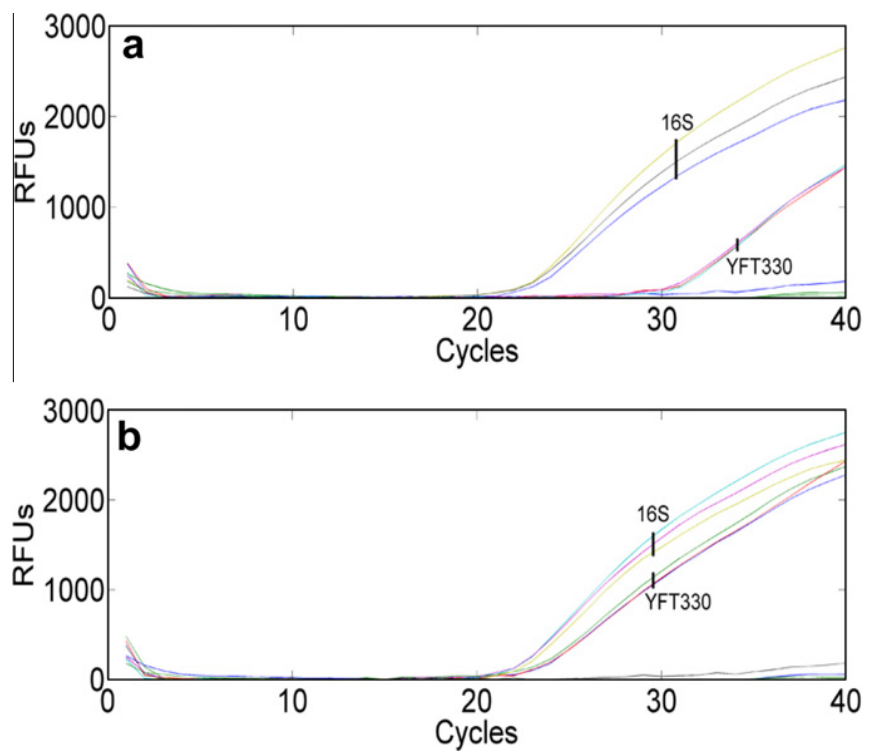

Fig. 4. The tuna cans (AGV and SH) were tested in triplicate real-time PCR reaction with only positive signals detected by the probe_YFT330 and probe_16S system. (a) Tuna can products from company AGV. (b) Tuna can products from company SH.

green system since the TagMan probes provided sufficient discrimination and no intraspecies variation was found.

\subsection{Species identification of canned product}

All of the tuna cans purchased from local markets were tested in triplicate and all the results showed positive signals in probe_YFT330 system, indicating the existence of YFT in their contents. In contrast, the other probe systems cannot detect positive signal from these cans. This result met our expectations as YFT and ALB are the two species most commonly used in canned tuna products. For the 3 cans purchased from company AGV, Ct values of probe_YFT330 were approximately 10-cycles delay relative to probe_16S (Fig. 4a). In contrast, the 3 cans purchased from company SH showed less difference between the $C t$ values of probe_YFT330 and probe_16S (Fig. 4b). Since the probe_16S system was designed as a universal probe to detect all Thunnus species, the delay of $C t$ values of probe_YFT330 might indicate more than one Thunnus species mixed in the cans.

\section{Conclusion}

This study demonstrated high identification success for BET PBT, SBT, and YFT by four species-specific TaqMan probes and one SYBR green system. The simplified one-step procedure offers advantages for large-scale examination and the applicability on canned products that are not applicable for other methods.

\section{Acknowledgments}

We are grateful to scientific observers for collecting the samples, to Ming-Ta Lee for useful discussion, and to Brian Jessop for reading the manuscript. The grants was supported by Fisheries Agency, Council of Agriculture, Executive Yuan (Taiwan, ROC), Project No. 96AS-15.1.2-FA-F2(9).

\section{Appendix A. Supplementary material}

Supplementary data associated with this article can be found, in the online version, at doi:10.1016/j.foodchem.2012.01.076.

\section{References}

Alary, R., Serin, A., Maury, D., Ben Jouira, H., Sirven, J. P., Gautier, M. F., et al. (2002) Comparison of simplex and duplex real-time PCR for the quantification of GMO in maize and soybean. Food Control, 13, 235-244.

Alvarado-Bremer, J. R., Stequert, B., Robertson, N. W., \& Ely, B. (1998). Genetic evidence for inter-oceanic subdivision of bigeye tuna (Thunnus obesus) populations. Marine Biology, 132, 547-557.

Ballin, N. Z., Vogensen, F. K., \& Karlsson, A. H. (2009). Species determination - Can we detect and quantify meat adulteration? Meat Science, 83, 165-174.

Bartlett, S. E., \& Davidson, W. S. (1992). FINS (forensically informative nucleotide sequencing) - a procedure for identifying the animal origin of biological specimens. Biotechniques, 12, 408-411.

Bertoja, G., Giaccone, V., Carraro, L., Mininni, A. N., \& Cardazzo, B. (2009). A rapid and high-throughput real-time PCR assay for species identification: Application to stockfish sold in Italy. European Food Research and Technology, 229, 191-195.

Bottero, M. T. Dalmasso, A., Cappelletti, M., Secchi, C., \& Civera, T. (2007) Differentiation of five tuna species by a multiplex primer-extension assay Journal of Biotechnology, 129, 575-580.

Botti, S., \& Giuffra, E. (2010). Oligonucleotide indexing of DNA barcode: identification of tuna and other scombrid species in food products. BMC Biotechnology, 10, 60.

Chow, S., \& Inoue, S. (1993). Intra-and interspecific restriction fragment length polymorphism in mitochondrial genes of Thunnus tuna species. Bulletin of the National Research Institute of Far Seas Fisheries, 30, 207-225.

Chow, S. \& Kishino, H. (1995). Phylogenetic relationships between tuna species of the genus Thunnus (Scombridae: Teleostei): inconsistent implications from morphology, nuclear and mitochondrial genomes. Journal of Molecular Evolution, $41,741-748$.

Chow, S., Okamoto, H., Miyabe, N., Hiramatsu, K., \& Barut, N. (2000). Genetic divergence between Atlantic and Indo-Pacific stocks of bigeye tuna (Thunnus obesus) and admixture around South Africa. Molecular Ecology, 9, 221-227.

Dalmasso, A., Fontanella, E., Piatti, P., Civera, T., Secchi, C., \& Bottero, M. T. (2007). Identification of four tuna species by means of real-time PCR and melting curve analysis. Veterinary Research Communications, 31, 355-357.

Durand, J. D. Collet, A. Chow, S., Guinand, B., \& Borsa, P. (2005). Nuclear and mitochondrial DNA markers indicate unidirectional gene flow of Indo-Pacific to Atlantic bigeye tuna (Thunnus obesus) populations, and their admixture of southern Africa. Marine Biology, 147, 313-322.

Gonzalez, E. G., Beerli, P., \& Zardoya, R. (2008). Genetic structuring and migration patterns of Atlantic bigeye tuna, Thunnus obesus (Lowe, 1839). BMC Evolutionary Biology, 8, 252.

Lopez, I., \& Pardo, M. A. (2005). Application of relative quantification TaqMan realtime polymerase chain reaction technology for the identification and quantification of Thunnus alalunga and Thunnus albacares. Journal of Agricultural and Food Chemistry, 53, 4554-4560.

Pardo, M. A., \& Pérez-Villareal, B. (2004). Identification of commercial canned tuna species by restriction site analysis of mitochondrial DNA products obtained by nested primer PCR. Food Chemistry, 86, 143-150.

Ponchel, F. Toomes, C. Bransfield, K. Leong, F. T. Douglas, S. H. Field, S. L, et al. (2003). Real-time PCR based on SYBR-Green I fluorescence. an alternative to the TaqMan assay for a relative quantification of gene rearrangements, gene amplifications and micro gene deletions. BMC Biotechnology, 3, 18.

Posada, D. (2008). JModelTest: phylogenetic model averaging. Molecular Biology and Evolution, 25, 1253-1256.

Rasmussen, R. S., \& Morrissey, M. T. (2008). DNA-based methods for the identification of commercial fish and seafood species. Comprehensive Reviews in Food Science and Food Safety, 7, 280-295.

Ririe, K. M. Rasmussen, R. P., \& Wittwer, C. T. (1997). Product differentiation by analysis of DNA melting curves during the polymerase chain reaction. Analytical Biochemistry, 245, 154-160. 
Rodriguez-Lazaro, D., Hernandez, M., Esteve, T., Hoorfar, J., \& Pla, M. (2003). A rapid and direct real time PCR-based method for identification of Salmonella spp. Journal of Microbiological Methods, 54, 381-390.

Takeyama, H., Chow, S., Tsuzuki, H., \& Matunaga, T. (2001). Mitochondrial DNA sequence variation within and between tuna Thunnus species and its application to species identification. Journal of Fish Biology, 58, 1646-1657.

Teletchea, F. (2009). Molecular identification methods of fish species: reassessment and possible applications. Reviews in Fish Biology and Fisheries, 19, 265-293.

Terio, V., Pinto, P. D., Decaro, N., Parisi, A., Desario, C., Martella, V., et al. (2010). Identification of tuna species in commercial cans by minor groove binder probe real-time polymerase chain reaction analysis of mitochondrial DNA sequences. Molecular and Cellular Probes, 24, 352-356.

Tseng, M. C., Shiao, J. C., \& Hung, Y. H. (2011). Genetic identification of Thunnus orientalis, T. thynnus, and T. maccoyii by a cytochrome $b$ gene analysis. Environmental Biology of Fishes, 91, 103-115.

Viñas, J., \& Tudela, S. (2009). A validated methodology for genetic identification of tuna species (Genus Thunnus). PLoS One, 4, e7606.

Wittwer, C. T., Herrmann, M. G., Moss, A. A., \& Rasmussen, R. P. (1997). Continuous fluorescence monitoring of rapid cycle DNA amplification. Biotechniques, 22, 130-131. 134-138. 